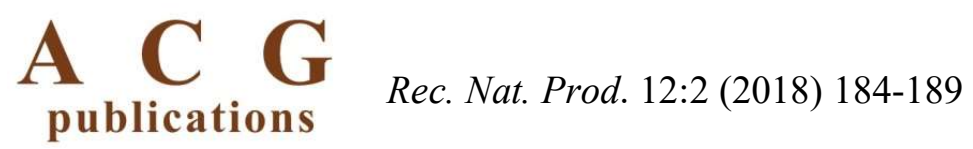

records of natural products

\title{
Chemical Composition of a New Taxon, Seseli gummiferum subsp. ilgazense, and its Larvicidal Activity against Aedes aegypti
}

\author{
Mine Kurkcuoglu $\odot^{1^{*}}$, Nurhayat Tabanca $\odot^{2,3}$, Abbas Ali $\odot^{2}$, \\ Ikhlas A. Khan $\odot^{2}$, Ahmet Duran $\odot^{4}$ and K. Husnu Can Baser $\odot^{1,5}$ \\ ${ }^{1}$ Anadolu University, Faculty of Pharmacy, Department of Pharmacognosy, 26470, Eskisehir, Türkiye \\ ${ }^{2}$ National Center for Natural Products Research, The University of Mississippi, University, MS 38677, USA \\ ${ }^{3}$ Current address: USDA-ARS, Subtropical Horticulture Research Station, 13601 Old Cutler Rd., Miami, FL \\ 33158 USA \\ ${ }^{4}$ Selcuk University, Faculty of Education, Department of Biology, 42090 Konya, Türkiye \\ ${ }^{5}$ Near East University, Faculty of Pharmacy, Department of Pharmacognosy, Nicosia, \\ Turkish Republic of Northern Cyprus
}

(Received May 07, 2017; Revised September 7, 2017; Accepted September 10, 2017)

\begin{abstract}
Mosquitoes are vectors for many pathogens and parasites that cause human diseases including dengue, yellow fever, West Nile, chikungunya, filariasis and malaria which cause high rates of human morbidity and mortality under extreme conditions. Plants are an excellent source for mosquito control agents because they constitute rich sources of bioactive chemicals. They are also biodegradable and environment-friendly. The present study reports on the larvicidal activity of the essential oil of Seseli gummiferum. subsp. ilgazense (Apiaceae) against Aedes aegypti larvae. Essential oil showed 100 and $70 \%$ mortality at 125 and $62.6 \mathrm{ppm}$, respectively, with no mortality at 31.25 ppm. Aerial parts of $S$. gummiferum subsp. ilgazense were subjected to hydrodistillation to yield $0.6 \%$ oil. The essential oil was analyzed by GC-FID and GC-MS techniques. The main constituents in the oil were sabinene (28.8\%), germacrene D (9.5\%) and $\alpha$-pinene (7.2\%).
\end{abstract}

Keywords: Asteraceae; Seseli gummiferum; essential oil; sabinene; germacrene D; $\alpha$-pinene; Aedes aegypti; larvicidal activity. (C) 2018 ACG Publications. All rights reserved.

\section{Plant Source}

Seseli L. is one of the largest genera in the family Apiaceae with 125 to 140 taxa and distributed in Europe, Asia, Africa, North America and Australia [1]. In Turkey, Seseli is represented by 13 taxa and $S$. gummiferum Pall. ex Sm. subsp. ilgazense A. Duran, O. Cetin \& M. Ozturk was recently reported as a new taxon [1]. In Turkish folk medicine, a few Seseli species such as S. tortuosum L. fruits is used as an emmenagogue and antiflatulence agent and S. libanotis Koch leaves are consumed as a vegetable in the

\footnotetext{
* Corresponding author: E-Mail: minekurkcuoglu@gmail.com

The article was published by ACG Publications

DOI: http://doi.org/10.25135/rnp.17.17.05.035
} 
eastern part of Turkey [2]. Essential oils of Seseli taxa of Turkey have been reviewed [3].

Seseli gummiferum Pall. ex Sm. subsp. ilgazense A. Duran, O. Cetin \& M. Ozturk was collected from Kastamonu: Ilgaz Mountain National Park, Kastamonu road, from Catoren village to Buyuk Hacet Hill, Turkey, and identified by Prof. Dr. Ahmet Duran. A voucher specimen was deposited at the Faculty of Education, Department of Biology, Konya, Turkey (Voucher specimen code: 8135).

\section{Previous Studies}

Previous phytochemical studies on Seseli species have reported the presence of coumarins, phenolic acids, phenylpropanoids and terpenoids [2]. Biological activities of Seseli essential oils have particularly focused on the antimicrobial, insect repellent and anti-inflammatory effects $[2,4,5]$.

Mosquitoes are vectors for many pathogens that cause human diseases including dengue fever, yellow fever, and malaria [6]. These illnesses can result in high rates of human morbidity and mortality in environments where appropriate medical resources are not available [7]. The primary method of mosquito control relies on the use of biological and/or synthetic insecticides [6]. Due to long term repeated chemical use, mosquito species have acquired resistance to commonly used insecticides, and especially against commercial pyrethroids [8-11]. Therefore, new and alternative mosquito control agents are emerging. Plant-derived products including essential oils (EOs) may offer an alternative and effective means of managing populations of mosquitoes [8-11]. As a part of our ongoing investigation of Turkish medicinal and aromatic plants, we report on the chemical composition of the aerial parts of S. gummiferum subsp. ilgazense, an endemic species from Turkey, and its larvicidal activity against $1^{\text {st }}$ instar Aedes aegypti (L).

\section{Present Study}

Isolation of the Essential Oil: Essential oil of S. gummiferum. subsp. ilgazense was hydrodistilled from dried aerial parts for $3 \mathrm{~h}$ using a Clevenger apparatus to yield $0.6 \%(\mathrm{w} / \mathrm{w})$.

Essential Oil Composition: The GC-MS and GC-FID analysis were carried out with an Agilent 5975 GCMSD and Agilent 6890N GC systems, respectively. Analysis conditions and identification of the oil 64 components are similar to our earlier study [6]. Sixty-two compounds constituting $91.1 \%$ of the essential oil were characterized. Sabinene $(28.8 \%)$, germacrene D $(9.5 \%)$ and $\alpha$-pinene $(7.2 \%)$ were the main constituent of essential oil (Table 1).

Larvicidal Activity: Aedes aegypti used in this study were from a laboratory colony maintained at USDAARS, Gainesville, Floridausing standard procedures [12]. The bioassays were performed as previosuly described [13]. Permethrin and DMSO were added as positive and negative controls, respectively. In larval screening bioassays, the $S$. gummiferum subsp. ilgazense EO killed $100 \% 11^{\text {st }}$ instar Ae. aegypti larvae at the concentration of $125 \mathrm{ppm}$ and followed by $70 \%$ mortality at $62.5 \mathrm{ppm}$ and no mortality at $31.25 \mathrm{ppm}$. Based on this moderate larvicidal activity, S. gummiferum subsp. ilgazense EO was not considered suitable for further dose-response bioassays. We previously investigated some of the major compounds, present in this oil for the larvicidal activity against $1^{\text {st }}$ instar Ae. aegypti larvae. For example, sabinene killed $40 \%$ of the larvae at $100 \mathrm{ppm}[8]$ and (+)- and (-)-terpinen-4-ol had no mortality at the highest screening dose of $100 \mathrm{ppm}$ [7]. We also found that (-)- $\alpha$-pinene $\left[\mathrm{LC}_{50}=49.5(43.5-56.1) \mathrm{ppm}\right]$ was slightly more toxic than $(+)$ - $\alpha$-pinene $\left[\mathrm{LC}_{50}=65.7(54.4-83.8) \mathrm{ppm}\right]$ against $1^{\text {st }}$ instar Ae. aegypti larvae [6].

A literature survey indicates the occurrence of sesquiterpenes germacrene D and bicyclogermacrene in S. gummiferum subsp. corymbosum and spathulenol in S. gummiferum subsp. gummiferum EOs as main constituents [14]. In the current study, S. gummiferum subsp. ilgazense EO stands out slightly in containing monoterpene hydrocarbons sabinene and $\alpha$-pinene, though germacrene $\mathrm{D}$ is also present as a second major constituent. Seseli species, in general, comprise mono- and sesquiterpenes as major constituents in their EOs as a common characteristic group of chemicals (Suplementary material, Table S1). 
Table 1. The Composition of the Essential Oil of S. gummiferum subsp. ilgazense

\begin{tabular}{|c|c|c|c|c|c|}
\hline \# & $\mathbf{R R I}^{\mathbf{a}}$ & $\mathbf{R R I}^{\mathbf{b}}$ & Compound & $\% *$ & Identification Method** \\
\hline 1 & 1014 & $1012^{d}$ & Tricyclene & $\mathrm{t}$ & MS \\
\hline 2 & 1032 & $1025^{\mathrm{c}, \mathrm{d}}$ & $\alpha$-Pinene & 7.2 & RRI, MS \\
\hline 3 & 1035 & $1026^{\mathrm{d}}$ & $\alpha$-Thujene & 1.2 & MS \\
\hline 4 & 1076 & $1077^{\mathrm{d}}$ & Camphene & 1.9 & RRI, MS \\
\hline 5 & 1093 & $1093^{c}$ & Hexanal & 0.3 & RRI, MS \\
\hline 6 & 1118 & $1117^{\mathrm{c}, \mathrm{d}}$ & $\beta$-Pinene & 2.0 & RRI, MS \\
\hline 7 & 1132 & $1122^{\mathrm{d}}$ & Sabinene & 28.8 & RRI, MS \\
\hline 8 & 1174 & $1167^{c}$ & Myrcene & 0.9 & RRI, MS \\
\hline 9 & 1188 & $1177^{\mathrm{d}}$ & $\alpha$-Terpinene & 1.2 & RRI, MS \\
\hline 10 & 1194 & $1174^{\mathrm{c}}$ & Heptanal & 0.1 & MS \\
\hline 11 & 1195 & $1192^{\mathrm{f}}$ & Dehydro-1,8-cineole & $\mathrm{t}$ & MS \\
\hline 12 & 1203 & $1212^{\mathrm{c}, \mathrm{d}}$ & Limonene & 1.8 & RRI, MS \\
\hline 13 & 1218 & $1209^{\mathrm{d}}$ & $\beta$-Phellandrene & 0.3 & RRI, MS \\
\hline 14 & 1244 & $1232^{\mathrm{f}}$ & Amyl furan & 0.1 & MS \\
\hline 15 & 1246 & $1232^{\mathrm{c}, \mathrm{d}}$ & $(Z)$ - $\beta$-Ocimene & 0.3 & RRI, MS \\
\hline 16 & 1255 & $1245^{\mathrm{d}}$ & $y$-Terpinene & 2.0 & RRI, MS \\
\hline 17 & 1266 & $1249^{\mathrm{c}}$ & (E)- $\beta$-Ocimene & 0.4 & MS \\
\hline 18 & 1280 & $\begin{array}{l}1268^{\mathrm{e}} \\
1282^{\mathrm{d}}\end{array}$ & $p$-Cymene & 2.5 & RRI, MS \\
\hline 19 & 1290 & $1282^{\mathrm{e}}$ & Terpinolene & 0.5 & RRI, MS \\
\hline 20 & 1296 & $1300^{c}$ & Octanal & 0.2 & RRI, MS \\
\hline 21 & 1406 & $1399^{\mathrm{f}}$ & $\alpha$-Fenchone & 0.1 & MS \\
\hline 22 & 1474 & $1459^{d}$ & trans-Sabinene hydrate & 0.6 & MS \\
\hline 23 & 1497 & $1488^{\mathrm{d}}$ & $\alpha$-Copaene & 0.4 & MS \\
\hline 24 & 1504 & $1495^{\mathrm{f}}$ & Daucene & 0.3 & MS \\
\hline 25 & 1535 & $1523^{\mathrm{d}}$ & $\beta$-Bourbonene & 0.2 & RRI, MS \\
\hline 26 & 1553 & $1538^{\mathrm{c}}$ & Linalool & 1.0 & RRI, MS \\
\hline 27 & 1556 & $1560^{\mathrm{e}}$ & cis-Sabinene hydrate & 0.4 & MS \\
\hline 28 & 1570 & $1584^{\mathrm{f}}$ & trans- $p$-Menth-2-en-1-ol & 0.4 & MS \\
\hline 29 & 1586 & $1575^{\mathrm{d}}$ & Pinocarvone & 0.2 & MS \\
\hline 30 & 1589 & $1576^{\mathrm{d}}$ & $\beta$-Ylangene & 0.1 & MS \\
\hline 31 & 1590 & $1579^{\mathrm{d}}$ & Bornyl acetate & 2.1 & RRI, MS \\
\hline 32 & 1594 & $1575^{\mathrm{f}}$ & trans- $\beta$-Bergamotene & 0.1 & MS \\
\hline 33 & 1597 & $1579^{d}$ & $\beta$-Copaene & 0.1 & MS \\
\hline 34 & 1600 & $1590^{d}$ & $\beta$-Elemene & 0.1 & MS \\
\hline 35 & 1611 & $1601^{\mathrm{d}}$ & Terpinen-4-ol & 4.6 & RRI, MS \\
\hline 36 & 1612 & $1608^{c}$ & $\beta$-Caryophyllene & 0.4 & RRI, MS \\
\hline 37 & 1683 & $1680^{d}$ & trans-Verbenol & 0.5 & MS \\
\hline 38 & 1687 & $1670^{\mathrm{c}}$ & $\alpha$-Humulene & 0.2 & RRI, MS \\
\hline 39 & 1704 & $1689^{d}$ & p-Muurolene & 1.0 & MS \\
\hline 40 & 1726 & $1722^{c}$ & Germacrene D & 9.5 & MS \\
\hline 41 & 1740 & $1723^{d}$ & $\alpha$-Muurolene & 0.5 & MS \\
\hline 42 & 1755 & $1734^{\mathrm{d}}$ & Bicyclogermacrene & 0.8 & MS \\
\hline 43 & 1772 & $1763^{f}$ & Citronellol & 0.4 & RRI, MS \\
\hline 44 & 1773 & $1755^{\mathrm{d}}$ & $\delta$-Cadinene & 0.6 & MS \\
\hline 45 & 1776 & $1763^{d}$ & -Cadinene & 0.3 & MS \\
\hline 46 & 1941 & $1921^{\mathrm{d}}$ & $\alpha$-Calacorene & 0.2 & MS \\
\hline 47 & 1945 & $1959^{\mathrm{g}}$ & 1,5-Epoxy-salvial(4)14-ene & 2.5 & MS \\
\hline 48 & 2001 & $1967^{\mathrm{c}}$ & Isocaryophyllene oxide & 0.2 & MS \\
\hline 49 & 2008 & $\begin{array}{l}1962^{d} \\
1979^{c}\end{array}$ & Caryophyllene oxide & 1.0 & RRI, MS \\
\hline 50 & 2045 & $2027^{\mathrm{e}}$ & Carotol & 2.4 & MS \\
\hline 51 & 2065 & $2073^{\mathrm{g}}$ & $p$-Mentha-1,4-dien-7-ol & 0.5 & MS \\
\hline 52 & 2069 & $2047^{\mathrm{d}}$ & Humulene epoxide-II & 0.6 & MS \\
\hline
\end{tabular}




\begin{tabular}{|c|c|c|c|c|c|}
\hline & & $2077^{\mathrm{c}}$ & & & \\
\hline 53 & 2123 & $2130^{g}$ & Salviadienol & 0.5 & MS \\
\hline \multirow[t]{2}{*}{54} & 2130 & $2126^{d}$ & Spathulenol & 2.5 & RRI, MS \\
\hline & & $2129^{c}$ & & & \\
\hline 55 & 2187 & $2165^{d}$ & T-Cadinol & 0.6 & MS \\
\hline 56 & 2209 & $2140^{\mathrm{h}}$ & T-Muurolol & 0.5 & MS \\
\hline 57 & 2243 & $2278^{g}$ & Torilenol & 0.6 & MS \\
\hline 58 & 2255 & $2227^{d}$ & $\alpha$-Cadinol & 0.6 & RRI, MS \\
\hline 59 & 2369 & $2366^{\mathrm{d}}$ & Eudesma-4(15), 7-dien- $1 \beta$-ol & 1.3 & MS \\
\hline 60 & 2565 & $2493^{h}$ & 14-Hydroxy- $\alpha$-muurolene & 0.2 & MS \\
\hline 61 & 2607 & $2547^{\mathrm{h}}$ & 14 -Hydroxy- $\delta$-cadinene & 0.2 & MS \\
\hline \multirow[t]{8}{*}{62} & 2622 & $2613^{f}$ & Phytol & 0.1 & MS \\
\hline & & & Monoterpene Hydrocarbons & 51.0 & \\
\hline & & & Oxygenated Monoterpenes & 8.7 & \\
\hline & & & Sesquiterpene Hydrocarbons & 14.8 & \\
\hline & & & Oxygenated Sesquiterpenes & 13.7 & \\
\hline & & & Diterpenes & 0.1 & \\
\hline & & & Others & 2.8 & \\
\hline & & & Total & 91.1 & \\
\hline
\end{tabular}

$\mathrm{RRI}^{\mathrm{a}}$ : RRI Relative retention indices experimentally calculated against $n$-alkanes;

$\mathrm{RRI}^{\mathrm{b}}$ : RRI from literature (c [15]; d [16]; e [17]; f [18]; g [19]; h [20]; g [21]) for polar column values;

$* \%$ calculated from FID data;

**Identification Method: Identification method based on the relative retention indices (RRI) of authentic compounds on a HP Innowax column; MS, identified on the basis of computer matching of the mass spectra with those of the inhouse Baser Library of Essential Oil Constituents, Adams [22], MassFinder [23] and Wiley [24] libraries

In conclusion, the weaker activity of $S$. gummiferum subsp. ilgazense EO may arise from its higher monoterpene content (51\%). To the best of our knowledge, this is the first report on the chemical composition of Seseli gummiferum subsp. ilgazense and its larvicidal activity against Ae. aegypti. Natural products will continue to be promising in the search for new and effective agents in pharmaceutical and agrochemical discovery.

\section{Acknowledgments}

This study was partly supported by the Deployed War-Fighter Protection Research Program Grant funded by the U.S. Department of Defense through the Armed Forces Pest Management Board. We thank Dr. James J. Becnel, Mosquito and Fly Research Unit, Center for Medical, Agricultural and Veterinary Entomology, USDA-ARS, Gainesville, for supplying Ae. aegypti eggs. Part of this work was presented as a poster presentation during the Inaugural Symposium of the Phytochemical Society of Asia (ISPSA 2015), 30 August - 2 September 2015, Tokushima, Japan.

\section{Disclosure Statement}

No potential conflict of interest was reported by the authors

\section{Supporting Information}

\section{ORCID}

Supporting Information accompanies this paper on http://www.acgpubs.org/RNP

Mine Kurkcuoglu: 0000-0002-9375-0294

Nurhayat Tabanca: $\underline{0000-0003-2802-8796}$

Abbas Ali: 0000-0001-5182-565X

Ikhlas A.Khan: 0000-0001-5464-4643

Ahmet Duran: 0000-0002-3675-1450

K. Husnu Can Baser: 0000-0003-2710-0231 


\section{References}

[1] O. Cetin, M. O. Seker and A. Duran (2015). A new subspecies of Seseli gummiferum (Apiaceae) from Ilgaz Mountain National Park, northern Turkey, Phytokeys 56, 99-110.

[2] E. Kupeli, A. Tosun and E. Yesilada (2006). Anti-inflammatory and antinociceptive activities of Seseli L. species (Apiaceae) growing in Turkey, J. Ethnopharmacol. 104, 310-314.

[3] K.H.C. Baser and N. Kirimer (2014). Essential oils of Anatolian Apiaceae - A Profile, Nat. Vol. Essent. Oils, 1, 1-50.

[4] S. Milosavljevic, V. Tesevoc, I. Vuckovic, M. Jadranin, V. Vajis, M. Sokovic, P. Janakovic, A. Javanovic (2007). Composition and antifungal activity of the essential oil of Seseli annuum wild-growing in Serbia, Fitoterapia 78, 319-322.

[5] A. Tosun, J. Chun, I. Jerkovic, Z. Marijanovic, M. A. Fenu, S. S. Aslan, C. I. G. Tuberoso and Y. S. Kim (2016). Chemical profiles and anti-inflammatory activity of the essential oils from Seseli gummiferum and Seseli corymbosum subsp. corymbosum, Nat. Prod. Commun. 11, 1523-1526.

[6] A. Ali, N. Tabanca, M. Kurkcuoglu, A. Duran, E. K. Blyhthe, I. A. Khan and K. H. C. Baser (2014). Chemical composition, larvicidal and biting deterrent activity of essential oils of two subspecies of Tanacetum argenteum (Lam.) willd and individual constituents against Aedes aegypti (L) (Diptera: Culicidae), J. Med. Entomol. 51, 824-830.

[7] N. Tabanca, B. Demirci, A. Ali, S. I. Khan, M. R. Jacob, Z. Aytac and I. A. Khan (2015). Composition and biological activity of Hypericum scabrum L. essential oil, Curr. Bioact. Compd. 11, 62-72.

[8] N. Tabanca, C. Avonto, M. Wang, J. F. Parcher, A. Ali, B. Demirci, V. Raman and I. A. Khan (2013). Comparative investigation of Umbellularia californica and Laurus nobilis leaf essential oils and identification of constituents active against Aedes aegypti, J. Agric. Food Chem. 61, 12283-12291.

[9] N. Tabanca, Z. Gao, B. Demirci, N. Techen, D. E. Wedge, A. Ali, B. J. Sampson, C. Werle, U.R. Bernier, I.A. Khan and K. H. C. Baser (2014). Molecular and phytochemical investigation of Angelica dahurica and $A$. pubescentis essential oils and their biological activity against Aedes aegypti, Stephanitis pyrioides and Colletotrichum species, J. Agric. Food Chem. 62, 8848-8857.

[10] J. F. Carroll, B. Demirci, M. Kramer, U. R. Bernier, N. M. Agramonte, K. H.C. Baser and N. Tabanca (2017). Repellency of the Origanum onites L. essential oil and constituents to the lone start tick and yello fever mosquito, Nat, Prod, Res. DOI: 10.1080/14786419.2017.1280485.

[11] S. O. Duke, C. L. Cantrell, K. M. Meepagala, D. E. Wedge, N. Tabanca and K.K. Schrader (2010). Natural toxins for use in pest management, Toxins 2, 1943-1962.

[12] J. W. Pridgeon, R. M. Pereira, J. J. Becnel, S. A. Allan, G.G. Clark and K. J. Linthicum (2008). Susceptibility of Aedes aegypti, Culex quinquefasciatus Say, and Anopheles quadrimaculatus Say to 19 Pesticides with different modes of action, J. Med. Entomol. 45, 82-87.

[13] A. Ali, Y-H Wang and I. A. Khan. (2015). Larvicidal and biting deterrent activity of essential oils of Curcuma longa, ar-turmerone, and curcuminoids against Aedes aegypti and Anopheles quadrimaculatus (Culicidae:Diptera). J. Med. Entomol. 52: 979-986.

[14] A. Tosun, T. Kodama, H. Nakanishi, M. Baba and T. Okuyama (2005). The composition of essential oils from Seseli species growing in Turkey, Nat. Medicines 59, 85-90.

[15] N. Kucukboyaci, B. Demirci, N. Adiguzel, B. Bani and K. H. C. Baser (2015). Volatile compounds from the aerial part and fruits of Grammosciadium pterocarpum Boiss. growing in Turkey, J. Essent. Oil Res. 27, 177181.

[16] H. E. Temel, B. Demirci, F. Demirci, F. Celep, A. Kahraman, M. Dogan and K. H. C Baser (2016). Chemical characterization and anticholinesterase effects of essential oils derived from Salvia species. J. Essent. Oil Res. 28, 322-331.

[17] L. Solis-Quispe, C. Tomaylla-Cruz, Y. Callo-Choquelvica, A. Solís-Quispe, I. Rodeiro, I. Hernández, M. D. Fernández and J. A. Pino (2016). Chemical composition, antioxidant and antiproliferative activities of essential oil from Schinus areira L. and Minthostachys spicata (Benth.) Epl. grown in Cuzco, Peru, J. Essent. Oil Res. 28, 234-240.

[18] V. I. Babushok, P. J. Linstrom and I. G. Zenkevich (2011). Retention indices for frequently reported compounds of plant essential oils, J. Phys. Chem. Ref. Data 40, 043101-47.

[19] http://webbook.nist.gov/ [Accessed on March 7th 2017].

[20] A. F. Barrero, J. E. Oltra, J. Altarejos, A. Barragan, A. R. Lara and R. Laurent (1993). Minor components in the essential oil of Juniperus oxycedrus L. wood, Flavour Frag. J. 8, 185-189.

[21] N. Tan, D. Stana, B. Sen, E. Tan, H. B. Altan, B. Demirci and M. Uzun (2016). Antimycobacterial and 
Antifungal Activities of Selected Four Salvia Species, Rec. Nat. Prod. 10, 593-603.

[22] R. P. Adams (2007). Identification of Essential Oil Components by Gas Chromatography/Mass Spectrometry. Allured Publ. Corp, Carol Stream, IL.

[23] D. H. Hochmuth (2008). MassFinder-4, Hochmuth Scientific Consulting, Hamburg, Germany.

[24] F. W. McLafferty and D.B. Stauffer (1989). The Wiley/NBS Registry of Mass Spectral Data, J. Wiley and Sons: New York.

$$
\underset{\substack{\text { publications } \\ \text { (C) 2018 ACG Publications }}}{\mathbf{C}}
$$

